\title{
Metode Dakwah Ustaz Darmansyah di Institut Pengajian Islam dan Dakwah
}

\author{
Mohd Azrul Nizam bin Junaidi ${ }^{1 *}$, Chatib Saefullah ${ }^{1}$, Henny Nuraini ${ }^{2}$ \\ ${ }^{1}$ Jurusan Komunikasi dan Penyiaran Islam, Fakultas Dakwah dan Komunikasi, UIN Sunan \\ Gunung Djati, Bandung \\ ${ }^{2} J u r u s a n$ Manajemen Dakwah, Fakultas Dakwah dan Komunikasi, UIN Sunan Gunung Djati, \\ Bandung \\ *Email : mobdazrulbinjunaidi@gmail.com
}

\begin{abstract}
ABSTRAK
Penelitian ini bertujuan untuk mengetahui bagaimana proses, materi dan hambatan dari metode dakwah. Objek penelitian adalah Ustadz Darmansyah di Institut Pengajian Islam dan Dakwah Sabah (IPDAS) di Kampung Menawo Daerah Keningau, Sabah Malaysia. Institut pengajian merupakan perguruan tinggi yang menyelenggarakan pendidikan akademik secara formal. Sama halnya dengan Institut Pengajian Pengajian Islam dan Dakwah Sabah (IPDAS), pengajian ini merupakan sebuah institusi pengajian yang banyak dibiayai secara awam melalui kerajaan negara atau setempat. Hasil penelitian ini menampakkan beberapa pendekatan dan kaedah yang digunakan oleh Ustaz Darmansyah ketika menyampaikan pesan dakwahnya. Beliau menggunakan metode dakwah bil lisan, mujadalah, mauidzotil hasanah dan bil hikmah. Metode dakwah ini adalah metode yang mudah untuk diterapkan dan mencakup segala segi kehidupan sehingga siapa saja yang ingin berdakwah tidak akan kesulitan mencari metode yang tepat untuk mendekati masyarakat sehingga ianya memudahkan kerja untuk mengajak kepada kebenaran, dan bersabar atas gangguan yang diterima.
\end{abstract}

\section{Kata Kunci : Metode; Dakwah; Pengajian}

\section{ABSTRACT}

This study aims to find out how the process, material and obstacles of the Da'wah Method. The object of research was Ustadz. Darmansyah at the Institute for Islamic Studies and the Preaching of Sabah (IPDAS) in Kampung Menawo in the Keningau Region, Sabah, Malaysia. The Institute of study is a college that organizes formal academic education. Similar to the Institute of Islamic Studies and the Preaching of the Sabah (IPDAS), it is a study institution that is largely financed through the state or local empire. The results of this study reveal several approaches and methods used by Ustaz. Darmansyah when delivering his da'wah 
message. He used the method of preaching bil bilally, mujadalah, manidzotil hasanah and bil wisdom. This method is a method that is easy to apply and covers all aspects of life so that anyone who wants to preach will have no trouble finding the right method to approach the community so that it makes it easy to work to bring to the truth, and be patient for the interference received.

\section{Keywords : Method; Religious Lecture; recitation}

\section{PENDAHULUAN}

Secara hakikat dakwah Islamiyah merupakan aktualisasi iman yang dimanifestasikan dalam kegiatan manusia beriman dalam masyarakat melalui cara tertentu, demi terwujudnya ajaran Islam dalam segala segi kehidupan, kegiatan (Jumontoro, 34:2010) tersebut sering disampaikan secara individu ataupun kelompok melalui berbagai metode dan sarana yang bertujuan memberi perubahan dalam kehidupan. Dalam proses dakwah banyak metode yang digunakan, namun metode tersebut haruslah sesuai dengan kondisi masyarakat yang dihadapi. Dakwah merupakan suatu aktifitas mulia yang bertujuan untuk memberikan informasi tentang Islam dan mengajak orang lain agar bersedia melakukan tindakan-tindakan yang mencerminkan nilai-nilai Islam. (Kassab, 2010:211).

Seorang da'i dalam usahanya untuk menyebarkan dan merealisasikan ajaran Islam di tengah-tengah kehidupan manusia, dia akan menghadapi masyarakat yang heterogen. Karena itu metode dakwah dalam proses dakwah pun harus sesuai dengan kadar pengetahuan masyarakat masing-masing. Adalah kenyataan bahwa dalam masyarakat terdapat beberapa golongan yang harus dihadapi oleh da'i dengan cara atau metode yang berbeda. Kegiatan dakwah akan efektif dan efisien apabila dimansifestasikan dengan cara yang tepat. Metode dakwah tidak boleh kaku dan statis baik dalam penerapan strategi maupun tekniknya, akan tetapi harus mampu mengikuti dinamika yang ada. Apabila metode dalam aplikasinya kaku dan statis, maka ajaran-ajaran yang didakwahkan tidak akan mendapatkan respon yang baik dari umat. Oleh karena itu, metode dakwah sebagai bagian dari sistem sangat berpengaruh dalam menentukan keberhasilan dakwah. Dakwah dapat dilakukan dengan cara billisan yang lebih banyak memfokuskan pada penekanan informatif persuasif dan cara bil-hal yang lebih menekankan pada hal-hal bersifat praktis yang mampu merangsang agar mad'unya lebih cepat melakukan perubahan dalam kegiatan sehari-hari. Sehubungan dengan masalah tersebut, maka da'i dituntut untuk mampu bersikap bijaksana dalam menerapkan metode dakwahnya yang sesuai dengan obyek atau mad'u yang dihadapi.

Dalam buku Komunikasi Dakwah, approach (pendekatan dakwah) merupakan cara yang dilakukan oleh para da'i atau Komunikator untuk mencapai suatu tujuan tertentu atas dasar hikmah dan kasih sayang. Artinya 
pendekatan dakwah haruslah bertumpu pada suatu pandangan human oriented, menempatkan penghargaan yang mulia atas diri manusia. Di dalam al-Qur'an banyak terdapat ayat-ayat yang memerintahkan agar umat Islam senantiasa menggerakkan dan menggiatkan usaha dakwah, sehingga ajaran Islam dapat senantiasa tegak dan dianut oleh umat Islam. Apa sebabnya Islam harus disiarkan? Hal ini adalah karena Islam merupakan rahmat bagi seluruh alam semesta. Allah SWT memerintahkan kepada Rasul-Nya Nabi Muhammad shallallahu 'alaihi wasallam agar menyeru manusia untuk menyembah Allah dengan cara yang bijaksana. Ibnu Jarir mengatakan bahwa yang diserukan kepada manusia ialah wahyu yang diturunkan kepadanya berupa Al-Qur'an, Sunnah, dan pelajaran yang baik yakni semua yang terkandung di dalamnya berupa larangan-larangan dan kejadian-kejadian yang menimpa manusia.

Pelajaran yang baik itu agar dijadikan peringatan buat mereka akan pembalasan Allah SWT terhadap mereka yang ingkar. Ayat ini memberi pemahaman kepada kita tentang kewajiban bagi setiap muslim untuk berdakwah. Dakwah tidak akan berhasil jika kita tidak memperhatikan rambu-rambunya. Maka cara berdakwah yang paling baik adalah mencontoh dakwahnya para Rasul Allah SWT. Itulah tiga cara berdakwah yang hendaknya engkau tempuh menghadapi manusia yang beraneka ragam peringkat dan kecenderungannya, jangan hiraukan cemooahan, atau tuduhan-tuduhan tidak berdasar kaum musyrikin dan serahkan urusanmu dan urusan mereka pada Allah, karena sesungguhnya Tuhanmu yang selalu membimbing dan berbuat baik kepadamu Dialah sendiri yang lebih mengetahui dari siapa pun yang menduga tahu tentang siapa yang bejat jiwanya sehingga tersesat dari jalan-Nya dan dialah saja juga yang lebih mengetahui orang-orang yang sehat jiwanya sehingga mendapat petunjuk. Seseorang muslim dan pendakwah yang sejati, dia mestilah berakhlak dengan akhlak-akhlak mahmudah dan meninggalkan sebarang akhlak-akhlak mazmumah, kerana ia merupakan teras kebahagiaan seseorang dalam menggapai redha Ilahi.

Akhlak yang mulia merupakan satu gambaran kesempurnaan Rasulullah shallallahu 'alaihi wasallam yang sentiasa hidup dalam jiwa seseorang insan yang beriman, di mana seseorang yan berakhlak mulia dari sudut rohani mahupun jasmani, bererti dia sentiasa bersama dengan Rasulullah shallallahu 'alaihi wasallam dan Rasulullah shallallahu 'alaihi wasallam hidup di dalam kehidupannya seluruhnya. Kebersamaan dengan Rasulullah shallallahu 'alaihi wasallam dalam konteks adab dan akhlak, merupakan satu nilai kemuliaan hidup yang utama di dalam menempuh hari-hari yang mendatang selaku hamba Allah SWT di dalam muka bumi ini, justeru ianya juga merupakan satu paket lengkap bagi seseorang da'i dalam menyampaikan dakwahnya kepada orang lain. Seharusnya para pendakwah perlu kembali menilai diri sendiri dan cuba menyesuaikan gerak kerja dakwah yang di lakukan selama ini dengan apa yang 
dilakukan oleh baginda shallallahu 'alaihi wasallam. Bermula dari kerja dakwah secara fardiyah maupun secara jama'ah, mengutamakan prinsip-prinsip rabbani yang telah dijelaskan agar keberlangsungan gerak kerja dakwah benar-benar menepati gaya gerak kerja Rasulullah shallallahu 'alaihi wasallam. Dalam sejarah perubahan masyarakat, mubaligh memang memiliki peran yang sangat besar dan universal. Ia nyaris memiliki andil dalam setiap lini dan detik dalam perubahan masyarakat (social Engineering) yang bermuara pada kesadaran kolektif masyarakat untuk melakukan perubahan. Maka mubaligh dinyatakan sebagai sumber dan inspirasi perubahan. tempat penelitian ini adalah di Institut Pengajian Pengajian Islam dan Dakwah Sabah (IPDAS), Malaysia. Seharusnya para pendakwah perlu kembali menilai diri sendiri dan cuba menyesuaikan gerak kerja dakwah yang di lakukan selama ini dengan apa yang dilakukan oleh baginda shallallahu 'alaihi wasallam. Bermula dari kerja dakwah secara fardiyah maupun secara jama'ah, mengutamakan prinsip-prinsip rabbani yang telah dijelaskan agar keberlangsungan gerak kerja dakwah benar-benar menepati gaya gerak kerja Rasulullah shallallahu 'alaihi wasallam. Berdasarkan pembatasan diatas, agar tidak melenceng dari konsentrasi penelitian, maka dirumuskan masalah-masalah yang sesuai dengan konsentrasi penelitian di atas. Adapun rumusan masalah pada penelitian ini adalah: a) Apakah metode dakwah yang digunakan oleh Ustadz Darmansyah kepada siswa di Institut Pengajian Islam dan Dakwah Sabah? b) Apakah pandangan mahasiswa di Institut Pengajian Islam dan Dakwah Sabah terhadap penyampaian dakwah Ustaz Darmansyah? c) Bagaimanakah penerimaan mahasiswa di Institut Pengajian Islam dan Dakwah Sabah terhadap penyampaian dakwah Ustaz Darmansyah?.

Metode penelitian yang akan digunakan dalam penelitian ini adalah metode penelitian kualitatif, yang dalam prosedur penelitiannya dapat menghasilkan analisis data deskiptif berupa kata kata tertulis atau lisan dari orang orang yang dapat diamati. Ada tiga pertimbangan mengapa penulis menggunakan metode tersebut adalah: Pertama, menyesuaikan metode kualitatif lebih mudah apabila berhadapan dengan kenyataan ganda. Kedua, metode ini menyajikan secara langsung hakikat hubungan antara peneliti dengan yang diteliti. Dan ketiga,metode ini lebih peka dan dapat menyesuaikan diri dengan banyak penajaman pengaruh bersama dan terdapat pola-pola nilai (Moleong. 2010;77).

\section{LANDASAN TEORITIS}

Dari segi bahasa kata metode berasal dari Bahasa Yunani yaitu methodos yang terdiri dari dua kata yaitu "meta" (melalui, menuju, mengikuti) dan "hetodos" (jalan atau cara). Kata methodos (metode) membawa arti jalan atau cara yang harus dilalui untuk mencapai sesuatu (Fananin, 2010;65). Metode juga berasal 
dari Inggris : methode yang artinya "cara" yaitu suatu cara untuk mencapai sutu cita-cita.

Metode lebih umum dari teknik yang dalam bahasa Inggrisnya : Technique. Dalam the concise Oxford Dictionary (1995) dinyatakan bahwa "method is a special from of procedure esp. in any branch of mental activity Technique adalah a means or method of achieving one's purpose, esp. skill fully" yang maknanya sesuatu alat atau cara untuk tujuan dengan cekatan atau praktis (Bahtiar, 1997;90). Dalam pengertian harfiahnya, metode adalah jalan yang harus dilakukan untuk mencapai suatu tujuan. Akan tetapi pengertian hakiki dari metode adalah segala sarana yang digunakan untuk tujuan yang diinginkan baik sarana tersebut secara fisik maupun non fisik. Sedangkan menurut Arif Burhan, metode adalah menunjukkan pada proses, prinsip serta prosedur yang digiunakan untuk mendekati masalah dan mencari jawaban atas masalah tersebut. (Burhan, 1992;127). Seseorang akan dapat mencapai kebenaran dalam sesuatu ilmu dengan adanya metode akan ilmu tersebut yang menjadi pengantar. Dakwah dapat dilakukan dengan cara bil-lisan yang lebih banyak memfokuskan pada penekanan informatif persuasif dan cara bil-hal yang lebih menekankan pada hal-hal bersifat praktis yang mampu merangsang agar mad'unya lebih cepat melakukan perubahan dalam kegiatan sehari-hari. Sehubungan dengan masalah tersebut, maka da'i dituntut untuk mampu bersikap bijaksana dalam menerapkan metode dakwahnya yang sesuai dengan obyek atau mad'u yang dihadapi.

Dengan adanya metode juga langkah-langkah akan menjadi lebih praktis dan sistematis. Sebagai contoh adalah dalam pembelajaran. Guru yang mengajar mahasiswa memerlukan metode tidak sesukanya saja untuk mengajar karena tujuan dari metode itu adalah untuk mencapai keberhasilan, Metode mengajar adalah sebagai alat untuk mencapai tujuan pengajaran yang ingin dicapai, sehingga semakin baik penggunaan metode mengajar semakin berhasillah pencapai tujuan, artinya apabila guru dapat memilih metode yang tepat yang disesuaikan dengan bahan pengajaran, murid, situasi kondisi, media pengajaran maka semakin berhasillah tujuan pengajaran yang ingin dicapai. (Soetomo, 1993;76). Didefinisikan juga bahwa metode adalah cara untuk menyampaikan pembicaraan dari pembicara dengan memilih kosa kata dan kalimat yang tepat. Dan diartikan juga metode sebagai cara untuk membuat atau cara memilih lafazh kemudian menyusunnya untuk diungkapkan dengan makna yang jelas dan mampu memberi pengaruh. Dari berbagai pengertian tentang metode di atas, maka dapat penulis pahami bahwa metode adalah suatu cara atau jalan yang harus dilalui dalam melaksanakan proses bimbingan agar tercapai tujuan yang diharapkan. Berdasarkan beberapa pendapat di atas juga, metode adalah caracara yang digunakan yang dilakukan guru dalam rangka proses kegiatan belajarmengajar, sehingga individu yang diajar akan dapat mencerna, menerima dan 
mampu mengembangkan bahan-bahan dan materi yang diajarkan sesuai dengan tujuan yang ingin dicapai.

Menurut bahasa, secara etimologi dakwah berasal dari bahasa arab, yaitu دعنة yang artinya memanggil (to call) mengajak (to summon) atau menyeru (to propose) (Munawir, 1994:21). Secara terminologi kata dakwah mengandung arti merangkul atau mengajak manusia dengan cara yang bijaksana untuk menuju jalan yang benar sesuai dengan petunjuk Allah SWT agar mendapatkan kesenangan, ketenangan, kenyamanan, keselamatan dan kebahagian di dunia dan di akhirat. (Umar, 78: 1998) Menurut Anwar Harjono dalam bukunya yang berjudul Dakwah dan Masalah Sosial Kemasyarakatan, mengatakan: "dakwah berarti mengajak manusia untuk senantiasa berbuat baik dalam hal menaati nilainilai yang sudah disepakati bersama dan sebaiknya mencegah manusia dari perbuatan munkar dalam hal ini melanggar nilai bersama tersebut" (Harjono, 1985:55). Menurut Dr.Quraish Shihab, dakwah adalah seruan atau ajakan kepada keinsyafan atau usaha mengubah situasi yang lebih baik dan sempurna, baik terhadap pribadi maupun masyarakat. Perwujudan dakwah bukan sekedar usaha peningkatan pemahaman dalam tingkah laku dan pandangan hidup saja, tetapi juga menuju sasaran yang lebih luas.( Shihab, 2007:89) Menurut DR. Wardi Bachtiar dalam bukunya Metodologi Penelitian Ilmu Dakwah, mengatakan dakwah merupakan suatu proses yang dilakukan agar dapat mengubah keadaan seseorang berada pada keadaan yang lebih baik serta tidak keluar dari kaidahkaidah ajaran agama Islam, intinya mengajak seseorang kepada jalan yang diridhai oleh Allah SWT (Bachtiar. 90:1997).

Arifin dalam bukunya Psikologi dan Beberapa Aspek Kehidupan Dakwah adalah kegiatan, ajaran tertulis, lisan dan tingkah laku yang dilakukan sadar dan berencana dalam usaha mempengaruhi manusia baik individual maupun kelompok, supaya dalam dirinya ada suatu pengertian, kesadaran, sikap penghayatan serta pengalaman agama sebagai pesan yang disampaikan padanya tanpa ada unsur paksaan. Dakwah Islam adalah satu kewajiban yang terpikul diatas pundak setiap muslim dalam posisi, profesi, dan dimanapun mereka berada baik secara perorangan ataupun secara kelompok. Menurut M. Syekh Khidir Husain dalam kitabnya Dakwah Ila Ishlah, mengatakan bahwa dakwah merupakan usaha memotivasi seseorang agar dapat berbuat baik dan mengikuti jalan petunjuk agama, serta melakukan amar mae ruf nahi munkar dengan tujuan mendapatkan kesuksesan dunia dan akhirat (Aziz, 2004: 112). Pertama, menyesuaikan metode kualitatif lebih mudah apabila berhadapan dengan kenyataan ganda. Kedua, metode ini menyajikan secara langsung hakikat hubungan antara peneliti dengan yang diteliti. Dan ketiga,metode ini lebih peka dan dapat menyesuaikan diri dengan banyak penajaman pengaruh bersama dan terdapat pola-pola nilai (Moleong. 2010;77). 
Institut merupakan kelembagaan perguruan tinggi yang mempunyai program studi dengan keilmuan sejenis. misalnya institut pertanian memiliki program studi pertanian, institut teknologi mengajarkan berbagai ilmu yang berhubungan dengan teknik. Disebutkan di dalam Kamus Dewan Edisi Ke-4, kata institut organisasi yang ditubuhkan untuk tugas tertentu seperti pendidikan, penyelidikan saintifik, dan lain-lain. Institut terdiri atas sejumlah fakultas yang menyelenggarakan pendidikan akademik dan/atau pendidikan vokasi dalam sejumlah ilmu pengetahuan, teknologi dan seni. Sama seperti universitas, institut juga boleh menyelenggarakan dua jenis Pendidikan tinggi juga, pendidikan akademi dan pendidikan vokasi. Beda fakultas-fakultas dalam sebuah institut berasal dari satu jenis keilmuan saja. Berbeda dengan universitas yang fakultasfakultasnya berasal dari berbagai jenis keilmuan. Misalnya, Institut Teknologi Bandung (ITB) yang hanya fokus kepada rumpun ilmu alam. Sehingga fakultasfakultas di ITB hanyalah yang terkait dengan ilmu alam seperti ilmu angkasa, ilmu kebumian, ilmu biologi, ilmu kimia, ilmu fisikan, dan sebagainya. Begitulah halnya dengan Institut Pengajian Islam dan Dakwah Sabah. Ianya dikategorikan sebagai sebuah institut karena lebih fokus kepada satu bidang keilmuan yaitu pada bagian dakwah saja.

\section{HASIL DAN PEMBAHASAN}

Ustadz Darmansyah bin Mohd Said atau lebih dikenali dengan panggilan Ustadz Darman merupakan anak kelahiran Sabah, Malaysia dan tepatnya lagi di daerah Lahad Datu. Lahir pada tanggal 10 Okrtober 1972. Mendapat pendidikan agama sejak awal dari orang tua sendiri. Mula bersekolah di provinsi Sabah juga. Beliau melanjutkan pelajaran di Institut Agama Islam Negeri (IAIN) Sultan Thoha Saifuddin Jambi, Sumatera Indonesia di peringkat Ijazah Sarjana Muda Siasah Jinayah dalam bidang Fiqh.

Mempunyai karakter yang bersahabat dengan sesiapa saja, beliau mudah sekali disukai oleh orang ramai terutamanya di kalangan mahasiswa. Sudah menikah dan mempunyai dua orang cahaya mata. Sebelum menjadi lecturer (dosen), beliau pernah mengajar di sekolah agama dan giat menggerakkan kegiatan di masjid. Setelah itu beliau mendapat tawaran mengajar di Institut Pengajian Islam dan Dakwah Sabah (IPDAS) dan tinggal di daerah Keningau sudah 10 tahun. Di sini lah beliau memulakan karir sebagai seorang dosen. Beliau ditugaskan untuk mengajar beberapa matakuliah kepada mahasiswa mengikut silabus yang telah ditetapkan. Antaranya ialah Fiqh Ibadah, Fiqh Muassarah, Aqidah dan Akhlak. Beliau tidak pernah mengikuti sebarang persatuan atau badan organisasi untuk dakwah karena beliau lebih suka melakukannya dengan bebas dan sukarela tanpa adanya penetapan dari manamana pihak asalkan apa yang beliau lakukan tidak melanggar undang-undang dan hukum agama yang sudah jelas. Namun setelah bergelar sebagai seorang 
dosen di sebuah institusi kerajaan, gerakan dakwah beliau seperti sebelumnya menjadi terhad disebabkan beliau harus lebih mendahulukan tanggungjawab mengajar mahasiswa-mahasiswa di institut ini. Setelah sekian lama menjadi tenaga pengajar beliau merasa semakin selesa dan tertarik untuk menyampaikan dakwahnya kepada golongan ini (mahasiswa). Beliau bukan saja disenangi oleh mahasiswa tetapi juga di kalangan dosen yang sama sebagai tenaga pengajar seperti beliau.

Institut Pengajian Islam \& Dakwah Sabah (IPDAS) dahulunya dikenali sebagai Pusat Latihan Dakwah Keningau merupakan sebuah institusi pengajian Islam di bawah pengurusan dan pentadbiran Jabatan Kemajuan Islam Malaysia (JAKIM) Cawangan Sabah. IPDAS terletak di daerah Keningau menawarkan dua program utama iaitu Program Sijil Pengajian Islam \& Dakwah dan Program Diploma Dakwah Islamiyyah. Institut Pengajian Islam Dan Dakwah Sabah (IPDAS) atau Pusat Latihan Dakwah Keningau (PLDK) ini telah dibangunkan pada bulan Oktober tahun 1979. Semasa mula beroperasi ianya dikendalikan oleh Majlis Ugama Islam Sabah (MUIS). Pada era kerajaan Parti Berjaya menerajui pemerintahan negeri Sabah terdapat ramai penduduk Sabah yang telah memeluk agama Islam tetapi tiada usaha susulan untuk memberi bimbingan dan tunjuk ajar. Oleh itu tujuan utama pusat ini dibangunkan adalah untuk memberi bimbingan agama kepada golongan muallaf ini. Kemudian mulai bulan Jun tahun 1984, Institut Pengajian Islam dan Dakwah Sabah telah diserahkan kepada kerajaan Persekutuan dan diuruskan pula oleh Bahagian Hal Ehwal Islam (BAHEIS), kini dikenali sebagai Jabatan Kemajuan Islam Malaysia (JAKIM) bagi menjalankan operasi yang serupa.Sejarah awal penubuhan pusat ini adalah untuk memberikan bimbingan dan didikan agama Islam kepada masyarakat Sabah yang baru memeluk agama Islam. Sehingga kini matlamat tersebut masih diteruskan bahkan diperluaskan lagi kepada remaja Islam asal. Jumlah peserta yang berjaya dilatih di pusat ini melebihi 5,000 orang. Lantaran peranannya yang sangat penting itu IPDAS terkenal di seluruh Sabah.

Kini hala tuju IPDAS lebih mencabar dalam menempuh era Islam globalisasi. Serentak dengan itu IPDAS melangkah setapak kehadapan untuk menaiktaraf pengajian ke peringkat lebih tinggi setanding dengan keperluan semasa iaitu melaksanakan kursus peringkat Diploma Pengajian Islam \& Dakwah dengan kerjasama Institut Kemahiran Islam Sarawak (IKMAS) JAKIM Cawangan Sarawak. Hasil resolusi Mesyuarat Ahli Lembaga Penasihat PusatPusat Latihan Jakim Cawangan Sabah yang ditubuhkan pada tahun 2012 yang dipersetujui oleh YB Menteri di Jabatan Perdana Menteri Malaysia dan YB Menteri Di Jabatan Ketua Menteri Sabah, bermula bulan Mei 2012, IPDAS dijangka akan merekrut pelatih diploma secara sepenuhnya di bangunan IPDAS sendiri tanpa perlu ke IKMAS lagi. 


\section{Metode yang digunakn Ustdz Darmansyah Dalam Dakwah}

Perihal metode dan teknik dalam proses bimbingan agama ada beberapa metode. Dalam teknik konseling terdapat beberapa tahap, yaitu, pertama, tahapan identifikasi masalah dan tahapan teknik konseling (Tajiri 2018;26). Menjaga hubungan baik kepada semua orang menjadi acuan hidup bagi Ustaz Darmanyah. Karena dengan menjaga hubungan kepada semua orang akan menjadikan setiap langkah beroleh kebaikan dan ini yang dimiliki oleh beliau layaknya seorang pendakwah. Sasaran utama dalam dakwah Ustaz Darmansyah adalah dari kalangan siswa di Institut Pengajian Islam dan Dakwah Sabah.

Kini hala tuju IPDAS lebih mencabar dalam menempuh era Islam globalisasi. Serentak dengan itu IPDAS melangkah setapak kehadapan untuk menaiktaraf pengajian ke peringkat lebih tinggi setanding dengan keperluan semasa iaitu melaksanakan kursus peringkat Diploma Pengajian Islam \& Dakwah dengan kerjasama Institut Kemahiran Islam Sarawak (IKMAS) JAKIM Cawangan Sarawak. Hasil resolusi Mesyuarat Ahli Lembaga Penasihat PusatPusat Latihan Jakim Cawangan Sabah yang ditubuhkan pada tahun 2012 yang dipersetujui oleh YB Menteri di Jabatan Perdana Menteri Malaysia dan YB Menteri Di Jabatan Ketua Menteri Sabah, bermula bulan Mei 2012, IPDAS dijangka akan merekrut pelatih diploma secara sepenuhnya di bangunan IPDAS sendiri tanpa perlu ke IKMAS lagi.Berdakwah di kampus merupakan bagian integral dari dakwah secara umum. Ia tidak berbeda dengan dakwah kepada manusia lain, hanya obyek dakwahnya memiliki ciri khas tersendiri, yaitu orangorang terpelajar atau mereka yang mengaku sebagai intelektual atau calon-calon intelektual.

Maka tujuan dakwah di kampus ini adalah mengajak para pelajar, mahasiswa dan dosen untuk mengenal Allah, Rasul dan Islam, dengan cara bijaksana dan pelajaran yang baik sehingga mereka beriman dengan keesaan Alllah, kelanjutan risalah, dan kebenaran Islam. Metode yang baik dan bijaksana dalam dakwah di kampus adalah metode yang dapat diterima oleh obyek dakwah kampus pelajar, mahasiswa, guru, dan dosen; dengan tidak menyalahi sunnah Rasulullah. Pelajar dan mahasiswa akan lebih mudah diajak mengenal Allah, Rasul, dan Islam melalui hal-hal yang akrab dan mereka geluti sehari-hari. Pendekatan keilmuan akan sangat membantu keberhasilan dakwah ini. Namun, menyentuh sisi fitrah lebih penting lagi karena obyek dakwah disini umumnya sangat kering dari unsur ruhiyah serta merindukan hidupnya fitrah mereka sebagai manusia yang tengah mencari bentuk pribadi dan jatidiri. Metode dakwah yang jelas digunakan oleh Ustaz Darmansyah adalah dakwah bil lisan. Metode dakwah yang dilakukan oleh seorang da'i dengan mengunakan lisannya pada saat aktivitas dakwah melalui bicara yang biasanya dilakukan dalam ceramah, pidato, dan khutbah. (Ikrima 2016; 49) Pada tahap kebudayaan 
manusia kegiatan membaca dan menulis belum ada. Maka dari itu, dakwah dilakukan dengan metode dakwah bil lisan.

Ustaz Darmansyah sering menggunakan metode ini ketika di masjid yaitu dalam menyampaikan ceramah atau pengajian. Dan beliau juga menggunakannya di kelas ketika sesi perkuliahan. Selain itu, metode ini juga beliau gunakan ketika berada di lapangan keluar bertemu masyarakat. Seterusnya adalah mujadalah. Seperti yang diketahui bahwa mujadalah itu adalah berbantahan dengan baik yaitu dengan jalan yang sebaik-baiknya dalam bermujadalah, antara lain dengan perkataan yang lunak, lemah lembut, tidak dengan ucapan yang kasar atau dengan mempergunakan sesuatu (perkataan) yang bisa menyadarkan hati membangunkan jiwa dan memerangi akal pikiran, ini merupakan penolakan bagi orang yang enggan melakukan perdebatan dalam agama. Hal ini dilakukan oleh Ustaz Darmansyah hanya ketika Bersama mahasiswanya di dalam kelas. Beliau sering membuat tanya jawab kepada mahasiswa yaitu memberikan persoalan dan kemudian hendaklah dijawab oleh mahasiswa dengan adanya argument yang kuat. Kaedah lainnya adalah beliau membagikan mahasiswa di dalam kelas kepada dua kelompok untuk saling berargumentasi. Pada mulanya penulis merasa begitu hairan kenapa begitu ramai sekali yang selesa dengan Ustaz Darmansyah. Dan lebih menghairankan lagi adalah apabila orang yang baru mengenali dan bertemu dengan beliau juga mudah sekali merasa senang dan selesa padahal baru pertama kali bertemu. Setelah diamati ternyata beliau mempunyai kelebihan ketika bertemu dengan semua orang yaitu membuat orang lain merasa selesa bukan saja dengan beliau tetapi juga dengan persekitaran. Dan inilah yang dikatakan hikmah dalam berdakwah.

Beliau mengatakan pernah suatu ketika dahulu ketika baru belajar untuk mempraktekkan ilmu dakwah yang sudah dipelajari beliau telah memilih satu perwatakan untuk dirinya ketika berdakwah. Dan beliau memilih untuk menjadi seorang yang tegas ketika menyampaikan dakwah. Namun dalam jangka masa yang Panjang beliau sendiri mengakui bahwa ada yang tidak benar dalam beliau melaksanakan dakwahnya. Ia bukan menjadikan orang-orang mendekat malah semakin menjauh kerana terlihat arogan. Setelah itu beliau belajar untuk memahami orang lain terlebih dahulu sebelum membuat tindakan. Oleh karena itulah sampai sekarang beliau sangat menjaga hubungan dengan semua orang dan sehingga ke hari ini beliau sangat disenangi bahkan kepada mereka yang baru pertama kali menemuinya. Ibnu Katsir menafsirkan kata hakim, dengan keterangannya, hakim dalam perbuatan dan ucapan, hingga dapat meletakan sesuatu pada tempatnya (Harjono 1985: 99). Dari berbagai pengertian ini, jelaslah bahwa apa yang dimaksud metode hikmah adalah metode meletakan sesuatu pada tempatnya, dengan demikian berarti mencakup semua teknik dakwah. Pengertian lain, hikmah adalah mengetahui suatu yang terbaik dengan 
pengetahuan yang paling baik. Dalam hal ini, Ustaz Darmansyah merupakan seorang yang teliti dalam dakwahnya dan tidak tergopoh-gapah. Tindakan yang sangat bijak terhadap mad'u adalah mengenali terlebih dahulu mad'u tersebut. Meskipun tidak mengenali keseluruhan tetapi cukuplah membuat mereka selesa dengan kita dan tidak sesekali membuat tindakan yang mengakibatkan mad'u menjauh. Beliau mengajak para siswa dengan penuh kelembutan tanpa paksaan dan menjaga hubungan adalah kunci utama. Pendekatan secara langsung terhadap para mahasiswa atau objek dakwah melalui berbagai macam cara ketika menyampaikan pesan. Dan yang paling ketara ketika beliau menyampaikan pesan, beliau sering membuat hal yang humoris. Tidak hanya dari setiap katanya yang berisi humor malah gerak tubuhnya ketika menyampaikan juga sangat mencuit hati. Kesan dari pendekatan yang digunakan oleh Ustaz Darmansyah di Institut Pengajian Islam dan Dakwah Sabah ini sangat memberikan kesan yang positif bukan saja kepada siswa tetapi juga dosen-dosen lainnya.

Dari wawancara yang dilakukan kepada siswa Institut Pengajian Islam dan Dakwah tentang sosok ustadz ini mereka terlalu senang sekali dan rata-rata mengatakan Ustaz Darmansyah merupakan seorang yang mampu menarik orang ramai untuk lebih tenang mempelajari ilmu agama. Setelah diamati dan dari hasil wawancara, dakwah yang telah dilakukan oleh Ustaz Darmansyah ini, beliau sangat mementingkan beberapa materi yang harus ada ketika menyampaikan pesan.

\section{Pandangan mahasiswa terhadap penyampaian dakwah Ustadz Darmansyah}

Dalam melaksanakan dakwah mensyiarkan ajaran-ajaran Islam kepada masyarakat, jalannya tidak selamanya akan lurus karena hambatan-hambatan pasti ada, baik dari da'i, mad'u, ataupun materinya. Maka dari itu metode yang tepat dan pas sesuai dengan situasi dan kondisi perlu artinya dakwah bisa berhasil apabila cara pelaksanaan dan metode digunakan sesuai dengan situasi masyarakat yang bersangkutan dengan harapan nantinya dakwah bisa diterima oleh masyarakat. Rasulullah shallallahu 'alaihi wasallam telah mengajarkan kepada kita metode berdakwah yang mudah untuk diterapkan dan mencakup segala segi kehidupan agar memberikan pandangan yang baik kepada mad'u. Hal tersebut merupakan salah satu pilar untuk mengatasi akhlak yang buruk dan meningkatkan akhlak yang baik kepada mahasiswanya (Ikrima 2016:135).

Seperti yang telah dilakukan oleh Ustaz Darman dalam dakwah beliau. Hasil wawancara yang dilakukan kepada mahasiswa di sini, mereka mengemukakan pandangan mereka terhadap penyampaian dakwah Ustaz Darman yang sememangnya mudah diterima umum bukan saja dari kalangan mahasiswa tetapi juga golongan lain meskipun kurang dalam pendidikan agama. Dengan cara bicara yang lembut dan pintar memasukkan humor dalam 
dakwahnya itu adalah sangat menyenangkan sekali. Pada mulanya penulis merasa begitu hairan kenapa begitu ramai sekali yang selesa dengan Ustaz Darmansyah. Dan lebih menghairankan lagi adalah apabila orang yang baru mengenali dan bertemu dengan beliau juga mudah sekali merasa senang dan selesa padahal baru pertama kali bertemu. Setelah diamati ternyata beliau mempunyai kelebihan ketika bertemu dengan semua orang yaitu membuat orang lain merasa selesa bukan saja dengan beliau tetapi juga dengan persekitaran. Dan inilah yang dikatakan hikmah dalam berdakwah. Beliau mengatakan pernah suatu ketika dahulu ketika baru belajar untuk mempraktekkan ilmu dakwah yang sudah dipelajari beliau telah memilih satu perwatakan untuk dirinya ketika berdakwah.( Muhaimin 2017;345) Dan beliau memilih untuk menjadi seorang yang tegas ketika menyampaikan dakwah. Namun dalam jangka masa yang Panjang beliau sendiri mengakui bahwa ada yang tidak benar dalam beliau melaksanakan dakwahnya. Ia bukan menjadikan orang-orang mendekat malah semakin menjauh kerana terlihat arogan. Setelah itu beliau belajar untuk memahami orang lain terlebih dahulu sebelum membuat tindakan. Oleh karena itulah sampai sekarang beliau sangat menjaga hubungan dengan semua orang dan sehingga ke hari ini beliau sangat disenangi bahkan kepada mereka yang baru pertama kali menemuinya. Ibnu Katsir menafsirkan kata hakim, dengan keterangannya, hakim dalam perbuatan dan ucapan, hingga dapat meletakan sesuatu pada tempatnya.

Dari berbagai pengertian ini, jelaslah bahwa apa yang dimaksud metode hikmah adalah metode meletakan sesuatu pada tempatnya, dengan demikian berarti mencakup semua teknik dakwah. (Ikrima 2016:24)Pengertian lain, hikmah adalah mengetahui suatu yang terbaik dengan pengetahuan yang paling baik. Dalam hal ini, Ustaz Darmansyah merupakan seorang yang teliti dalam dakwahnya dan tidak tergopoh-gapah. Tindakan yang sangat bijak terhadap mad'u adalah mengenali terlebih dahulu mad'u tersebut. Meskipun tidak mengenali keseluruhan tetapi cukuplah membuat mereka selesa dengan kita dan tidak sesekali membuat tindakan yang mengakibatkan mad'u menjauh. Beliau mengajak para siswa dengan penuh kelembutan tanpa paksaan dan menjaga hubungan adalah kunci utama. Pendekatan secara langsung terhadap para mahasiswa atau objek dakwah melalui berbagai macam cara ketika menyampaikan pesan. Dan yang paling ketara ketika beliau menyampaikan pesan, beliau sering membuat hal yang humoris. Tidak hanya dari setiap katanya yang berisi humor malah gerak tubuhnya ketika menyampaikan juga sangat mencuit hati. Kesan dari pendekatan yang digunakan oleh Ustaz Darmansyah di Institut Pengajian Islam dan Dakwah Sabah ini sangat memberikan kesan yang positif bukan saja kepada siswa tetapi juga dosen-dosen lainnya. Dari wawancara yang dilakukan kepada siswa Institut Pengajian Islam dan Dakwah tentang sosok 
ustadz ini mereka terlalu senang sekali dan rata-rata mengatakan Ustaz Darmansyah merupakan seorang yang mampu menarik orang ramai untuk lebih tenang mempelajari ilmu agama. Setelah diamati dan dari hasil wawancara, dakwah yang telah dilakukan oleh Ustaz Darmansyah ini, beliau sangat mementingkan beberapa materi yang harus ada ketika menyampaikan pesan. Dan beliau memilih untuk menjadi seorang yang tegas ketika menyampaikan dakwah. Namun dalam jangka masa yang Panjang beliau sendiri mengakui bahwa ada yang tidak benar dalam beliau melaksanakan dakwahnya. Ia bukan menjadikan orang-orang mendekat malah semakin menjauh kerana terlihat arogan. Setelah itu beliau belajar untuk memahami orang lain terlebih dahulu sebelum membuat tindakan.

Demikianlah yang diajarkan oleh Rasululullah SAW, beliau memulai dakwah dengan memperkokoh ideologi, menanamkan dasar-dasar tauhid serta pondasi-pondasi utama agama Islam. Sebagaimana beliau juga berpesan kepada para sahabat agar memulai dakwah dengan penanaman pondasi dasar Islam. Itulah yang dilakukan oleh Ustaz Darman. Dari wawancara yang dilakukan kepada siswa Institut Pengajian Islam dan Dakwah tentang sosok ustadz ini mereka terlalu senang sekali dan rata-rata mengatakan Ustaz Darmansyah merupakan seorang yang mampu menarik orang ramai untuk lebih tenang mempelajari ilmu agama. Setelah diamati dan dari hasil wawancara, dakwah yang telah dilakukan oleh Ustaz Darmansyah ini, beliau sangat mementingkan beberapa materi yang harus ada ketika menyampaikan pesan. a) akidah, Masalah pokok yang menjadi materi dakwah adalah akidah islamiyah. Aspek akidah ini yang akan membentuk moral manusia.

Oleh karena itu, sampai sekarang beliau sangat menjaga hubungan dengan semua orang dan sehingga ke hari ini beliau sangat disenangi bahkan kepada mereka yang baru pertama kali menemuinya. Ibnu Katsir menafsirkan kata hakim, dengan keterangannya, hakim dalam perbuatan dan ucapan, hingga dapat meletakan sesuatu pada tempatnya. Dari berbagai pengertian ini, jelaslah bahwa apa yang dimaksud metode hikmah adalah metode meletakan sesuatu pada tempatnya, dengan demikian berarti mencakup semua teknik dakwah. Pengertian lain, hikmah adalah mengetahui suatu yang terbaik dengan pengetahuan yang paling baik. Dalam hal ini, Ustaz Darmansyah merupakan seorang yang teliti dalam dakwahnya dan tidak tergopoh-gapah. Tindakan yang sangat bijak terhadap mad'u adalah mengenali terlebih dahulu mad'u tersebut. Meskipun tidak mengenali keseluruhan tetapi cukuplah membuat mereka selesa dengan kita dan tidak sesekali membuat tindakan yang mengakibatkan mad'u menjauh. 


\section{Penerimaan mahasiswa terhadap penyampaian dakwah Ustadz Darmansyah}

Mahasiwa dikatakan sebagai masa mencari jati diri. Kecenderungan jiwa yang labil sering kali menjadi kendala dalam mendakwahi mereka. Pasang surut semangat serta goyah dalam pendirian merupakan hal yang biasa menimpa para remaja. Hal ini lebih dipengaruhi oleh faktor internal, yaitu ideologi yang kurang kokoh. Akibatnya pola pikir menjadi plin-plan, dari situ pula terlahir sikap yang tidak istiqomah. Solusi terbaik untuk mengatasi permasalahan ini adalah dengan menanamkan prinsip-prinsip dasar agama Islam terlebih dahulu sebelum mendakwahkan yang lainnya. Terlebih dakwah sebagai kewajiban agama islam yang harus dilaksanakan oleh umat islam merupakan ikhtiar dan usaha yang tidak mengenal henti (Enjang, 2017;348). Namun dalam jangka masa yang Panjang beliau sendiri mengakui bahwa ada yang tidak benar dalam beliau melaksanakan dakwahnya. Ia bukan menjadikan orang-orang mendekat malah semakin menjauh kerana terlihat arogan. Setelah itu beliau belajar untuk memahami orang lain terlebih dahulu sebelum membuat tindakan.

Demikianlah yang diajarkan oleh Rasululullah shallallahu 'alaihi wasallam, beliau memulai dakwah dengan memperkokoh ideologi, menanamkan dasardasar tauhid serta pondasi-pondasi utama agama Islam. (Ikrima 2016;27) Sebagaimana beliau juga berpesan kepada para sahabat agar memulai dakwah dengan penanaman pondasi dasar Islam. Itulah yang dilakukan oleh Ustaz Darman. Dari wawancara yang dilakukan kepada siswa Institut Pengajian Islam dan Dakwah tentang sosok ustadz ini mereka terlalu senang sekali dan rata-rata mengatakan Ustaz Darmansyah merupakan seorang yang mampu menarik orang ramai untuk lebih tenang mempelajari ilmu agama. Setelah diamati dan dari hasil wawancara, dakwah yang telah dilakukan oleh Ustaz Darmansyah ini, beliau sangat mementingkan beberapa materi yang harus ada ketika menyampaikan pesan. a) akidah, Masalah pokok yang menjadi materi dakwah adalah akidah islamiyah. Aspek akidah ini yang akan membentuk moral manusia.

Oleh karena itu, yang pertama kali dijadikan materi dalam dakwah islam adalah masalah keimanan. Pembenahan aqidah merupakan asas dasar Dienul Islam. Tidaklah berlebihan sebab syahadat Laa Ilaaha Illallah Muhammadur Rasulullah merupakan rukun Islam yang pertama. Dan para rasul pertama kali menyeru kaumnya untuk membenahi aqidah mereka. Sebab aqidah merupakan dasar pondasi seluruh amal ibadah dan perbuatan yang dilakukan (Harjono, 1985:67). Tanpa pembenahan aqidah amal menjadi tiada berguna Dari ayat-ayat diatas dan beberapa ayat lainnya jelaslah bahwa urgensi aqidah merupakan prioritas yang utama dan pertama dalam dakwah. Seruan dakwah pertama kali adalah kepada pembenahan aqidah. Rasulullah Shallallahu 'alaihi wa sallam bermukim di kota Mekkah setelah diangkat menjadi rasul selama tiga belas tahun 
menyeru umat manusia kepada pembenahan aqidah, yakni kepada tauhid. Tidaklah diturunkan kewajiban-kewajiban ibadah kecuali setelah beliau hijrah ke Madinah. Memang benar, ibadah shalat diwajibkan ketika beliau berada di Makkah sebelum hijrah, akan tetapi syariat-syariat lainnya diwajibkan atas beliau setelah hijrah ke Madinah.

Hal itu menunjukkan bahwa amal ibadah itu baru dituntut setelah pembenahan aqidah. b) Syari'ah, Hukum atau syariah sering disebut sebagai cermin peradaban dalam pengertian bahwa ketika ia tumbuh matang dan sempuna, maka peradaban mencerminkan dirinya dalam hukum-hukumnya. Pelaksanaan syariah merupakan sumber yang melahirkan peradaban islam, yang melestarikan dan melindunginya dalam sejarah. Islam merupakan kenikmatan hakiki yang akan mengantarkan manusia kepada kehidupan yang sempurna. Dan manusia sama sekali tidak bernilai, sebelum ia mengenal sembahannya sesuai dengan tuntunan Islam, sebelum mengenal alam semesta ini sesuai dengan petunjuk Islam, sebelum memahami diri dan perannya di alam ini serta kemuliaannya di sisi Rabbnya sebagaimana dituturkan Islam yang telah diridhai Allah. Manusia tidak mempunyai harga apapun sebelum ia merdeka dari penyembahan terhadap sesama makhluk menuju peribadahan kepada Rabb semua makhluk.

Tanpa nilai-nilai yang telah Allah anugerahkan melalui agama Islam yang lurus ini, manusia akan hidup layaknya binatang ternak yang berkeliaran, bahkan lebih sesat darinya, karena membalas nikmat Allah ini (berupa agama Islam) dengan kekufuran. umat manusia benar-benar membutuhkan syari'at Islam, lantaran mengandung seluruh kemaslahatan yang besar, mempedulikan mashalih manusia di dunia maupun di akhirat dan menjadi sarana untuk menggapai keselamatan dan kebahagiaan. Allah menjelaskan dalam kitab-Nya, bahwa syari'at-Nya merupakan shirâthul-mustaqim (jalan yang lurus), jalan yang lurus dan metode yang benar. Siapa saja yang konsisten di atasnya, niscaya akan selamat. Dan barang siapa yang berpaling, maka akan binasa c) Muamalah Islam adalah agama yang lebih banyak memperhatikan aspek kehidupan sosial daripada aspek kehidupan ritual. Ibadah dalam muamalah di sini, diartikan sebagai ibadah yang mencakup hubungan dengan Allah dalam rangka mengabdi kepada Allah. Beliau melihat hal ini dipandang ringan di kalangan mahasiswa makanya beliau sangat menerapkannya. d) Akhlak Materi akhlak tidak kalah penting. Pembahasan mengenai akhlak selalu berkaitan dengan tabiat atau kondisi temperature batin mempengaruhi perilaku manusia. Akhlak meliputi akhlak terhadap khalik dan akhlak terhadap makhluk.

Dengan akhlak, dapat mengantarkan manusia kepada tujuan hidupnya yang tinggi, yaitu kebahagiaan, dan tentang berbagai kejahatan yang dapat merintangi tujuan tersebut. karena itulah sampai sekarang beliau sangat menjaga hubungan dengan semua orang dan sehingga ke hari ini beliau sangat disenangi 
bahkan kepada mereka yang baru pertama kali menemuinya. Ibnu Katsir menafsirkan kata hakim, dengan keterangannya, hakim dalam perbuatan dan ucapan, hingga dapat meletakan sesuatu pada tempatnya. Dari berbagai pengertian ini, jelaslah bahwa apa yang dimaksud metode hikmah adalah metode meletakan sesuatu pada tempatnya, dengan demikian berarti mencakup semua teknik dakwah. Pengertian lain, hikmah adalah mengetahui suatu yang terbaik dengan pengetahuan yang paling baik. Dalam hal ini, Ustaz Darmansyah merupakan seorang yang teliti dalam dakwahnya dan tidak tergopoh-gapah. Tindakan yang sangat bijak terhadap mad'u adalah mengenali terlebih dahulu mad'u tersebut. Meskipun tidak mengenali keseluruhan tetapi cukuplah membuat mereka selesa dengan kita dan tidak sesekali membuat tindakan yang mengakibatkan mad'u menjauh.

\section{PENUTUP}

Dari hasil penelitian yang telah penulis lakukan di Institut Pengajian Islam dan Dakwah Sabah yang berlokasi di Kampung Menawo daerah Keningau, Sabah Malaysia. Ustaz Darmansyah ketika melakukan dakwah beliau sangat berhati-hati dan mejaga perkataan yang dikeluarkan. Hal ini dapat dilihat ketika beliau mengajar semasa sesi perkuliahan. Mengenai metode dakwah Ustaz Darmansyah bin Mohd Said dalam pelaksaan dakwahnya di Institut Pengajian Islam dan Dakwah Sabah (IPDAS), dapat disimpulkan beliau menerapkan beberapa metode berikut:

Pertama Dakwah bil Lisan Merupakan metode dakwah yang dalam aktivitas dakwahnya menggunakan lisan. Dakwah bil lisan contohnya ceramah, tabligh akbar, khutbah dan lain sebagainya. Dalam hal ini jelas sekali karena beliau sering melakukan ceramah di masjid Instiut Pengajian Islam dan Dakwah Sabah.

Kedua Mujadalah Merupakan metode tukar pendapat yang dilakukan dua belah pihak secara sinergis dan tidak melahirkan permusuhan. Hal itu dilakukan dengan tujuan agar lawan menerima pendapat yang diajukan dengan memberikan argumentasi dan bukti yang kuat. Selain itu, metode ini juga beliau gunakan ketika berada di lapangan keluar bertemu masyarakat. Seterusnya adalah mujadalah. Seperti yang diketahui bahwa mujadalah itu adalah berbantahan dengan baik yaitu dengan jalan yang sebaik-baiknya dalam bermujadalah, antara lain dengan perkataan yang lunak, lemah lembut, tidak dengan ucapan yang kasar atau dengan mempergunakan sesuatu (perkataan) yang bisa menyadarkan hati membangunkan jiwa dan memerangi akal pikiran, ini merupakan penolakan bagi orang yang enggan melakukan perdebatan dalam agama

Ketiga Dakwah Mau'izah Hasanah Merupakan salah satu metode dalam dakwah untuk mengajak ke jalan Allah dengan memberikan nasihat atau membimbing dengan lemah lembut agar mereka mau berbuat baik. 
Ke empat Dakwah bil Hikmah merupakan metode dakwah yang disampaikan dengan cara yang bijaksana. Metode ini mengedepankan cara persuasif sehingga orang-orang yang didakwahi tidak merasa dipaksa, merasa tertekan atau pun menimbulkan konflik. Sama halnya seperti yang sering dilakukan oleh Ustadz Darmansyah karena ini adalah yang paling utama.

Dapatan dari penelitian ini juga menunjukkan bahwa Institut Pengajian Islam dan Dakwah selama ini telah banyak menarik non-Muslim untuk memeluk agama Islam. Hal ini dapat dibuktikan dengan melihat purata penduduk Islam di sekitar kampung berdekatan Institut Pengajian Islam dan Dakwah Sabah semakin bertambah. Dapat dilihat juga dari latar belakang mahasiswa di sini yang banyak dari muallaf. Ini adalah hasil dari kerja dakwah mereka di lapangan selama bertahun-tahun masuk ke masyarakat dan Kawasan pedalaman. Dari kesimpulan di atas, akhirnya penulis dapat memaparkan beberapa saran yang penting dengan penelitian ini. Setelah selesai memaparkan jawaban dari rumusan masalah, ada beberapa hal yang perlu disampaikan peneliti, meskipun secara keseluruhan dari metode dakwah Ustadz Darmansyah bin Mohd Said sudah cukup baik yang dibuktikan melalui adanya perubahan dari kebiasaan mahasiswa menjadi masyarakat yang paham serta mengerti dan mau menjalankan tuntunan agama

\section{DAFTAR PUSTAKA}

Arifin, M. (2000). Psikologi Dakwah Suatu Pengantar Studi. Jakarta: Bumi Aksara. Aziz, M. A. (2004). Ilmu Dakwah. Jakarta: Kencana.

Bahtiar, W. (1997). Metodologi Penelitian Ilmu Dakwah. Jakarta: Logos.

Burhan, A. (1992). Pengantar Metode Kualitatif. Surabaya: Usaha Nasional.

Fanani, D. M. (2010). Metode Studi Islam. Yogyakarta: Pustaka Pelajar.

Harjono, A. (1985). Dakwah dan Masalab Sosial Kemasyarakatan. Jakarta: Media Dakwah.

Ikrima, A. Dkk. (2016). Dakwah Majelis Rasulullah dan Kecintaan Jamaah kepada Dakwah Islam dalam Tabligh: Jurnal Komunikasi Penyiaran Islam. 2 (1) 19-36

Jumontoro, T. (2001). Psikologi Dakwah Dengan Aspek-Aspek Kejiwaan yang Qur'ani. Jakarta: Wonosobo.

Kassab, S. A. (2010). Metode Dakwah Al-Qaradhawi. Jakarta: Pustaka Al-Kauthar.

Muhaimin, E. (2017). Dakwah Digital Akademisi Dakwah dalam Jurnal Ilmu Dakwah.11 (2) 341-356

Munawir, W. (1994). Kamus Al-Munawir. Surabaya: Pustaka Agresif.

Shihab, Q. (2007). Membumikan Al-Quran, Fungsi dan Peran Wabyu Dalam Kehidupan. Bandung: Mizan.

Soetomo. (1993). Dasar-Dasar Interaksi Belajar Mengajar. Surabaya: Usaha Nasional. 
Tajiri, H. (218). Pendekatan Konseling Spiritual dalam Penyembuhan Pasien Narkoba di Inabah VII Tasikmalaya dalam Anida (Aktualisasi Nuansa Ilmu Dakwah). 18 (1) 21-40

Umar, T. Y. (1998). Imu Dakwah. Jakarta: Wijaya. 